\title{
Design and Manufacturing of Thermoelectric Mini Portable Refrigerator using Autodesk Fusion 360 and Additive Manufacturing
}

\author{
Angamuthu. K, Ashu Dominic, Arun Kumar. H, Sahil. S, Jofin Sam
}

\begin{abstract}
The objective of this project is to develop portable thermoelectric refrigeration whose casing is designed using Autodesk Fusion 360 and manufactured by $3 D$ printing. This refrigerator consists of thermoelectric module as cooling generator along with insulated cabin, thermostat and charging unit. Thermoelectric elements perform the same cooling function as Freon-based vapour compression or absorption refrigerators. The design of the refrigeration is based on the principle of thermoelectric module (i.e. Peltier effect) to create a hot side and a cold side. The cold side of the thermoelectric module is used for refrigeration purposes. On the other hand, the heat from the hot side of the module is rejected to the surroundings with the help of heat sinks and fan. Based on the heat load calculations, the thermoelectric module is selected. The system is fabricated and experimentally tested for the time taken to cool to the required temperature. The results showed that the system can maintain the temperature of approximately $10{ }^{\circ} \mathrm{C}$ with minimum power consumption of 64 Watt.
\end{abstract}

Keywords: Thermoelectric refrigeration, Peltier effect, miniportable refrigerator.

\section{INTRODUCTION}

Refrigeration and cooling is an important industrial process for many applications including preservation and storage of food products, dairy products, medicines, electronic devices and automobile air conditioning. There are many methods of refrigeration such as non-cyclic, cyclic based on thermodynamic cycles and thermo-electric.

Manuscript published on January 30, 2020.

* Correspondence Author

Dr.K.Angamuthu*, Department of Mechanical Engineering, Providence College of Engineering, Chengannur, Kerala, India, Email: angamuthu@yahoo.com

Ashu Dominic, Department of Mechanical Engineering, Providence College of Engineering, Chengannur, Kerala, India, Email: ashudominic433@gmail.com

Arun Kumar.H, Department of Mechanical Engineering, Providence College of Engineering, Chengannur, Kerala, India, Email: arunkumarh514@gmail.com

Sahil.S, Department of Mechanical Engineering, Providence College of Engineering, Chengannur, Kerala, India, Email: sahilshareef007@gmail.com

Jofin Sam, Department of Mechanical Engineering, Providence College of Engineering, Chengannur, Kerala, India, Email: jofin.sj163p@gmail.com

(C) The Authors. Published by Blue Eyes Intelligence Engineering and Sciences Publication (BEIESP). This is an open access article under the CC-BY-NC-ND license (http://creativecommons.org/licenses/by-nc$\underline{\mathrm{nd} / 4.0 /)}$
The conventional refrigeration methods such as vapour compression and vapour absorption refrigeration are detrimental to environment. Many researches are being carried out to find out alternate methods of refrigeration to avoid environmental pollution. Thermoelectric cooling uses Peltier effect to create a heat flux between the junctions of two different types of materials. This effect is commonly used in camping and portable coolers and for cooling electronic components and small instruments [1]. Magnetic refrigeration, or adiabatic demagnetization, is a cooling technology based on the magneto caloric effect [2]. Thermo acoustic refrigeration uses sound waves in a pressurized gas to drive heat transfer and heat exchange [3]. Many Stirling cycle heat engines can be run backwards to act as a refrigerator and therefore these engines have a niche use in cryogenics [4]-[5].

Many researchers reported about the Peltier thermoelectric refrigeration system. This thermo electric cooling system has many advantages such as small size, less weight, no refrigerant and moving parts such as compressor and can be operated using DC power supply. This system finds application in portable refrigerator and ice boxes, cooling of beverage can and picnic baskets, cooling for laser diodes, blood analysers, integrated circuit chips and industrial temperature control [6]-[7]. Elavarasan E et al [8] developed a mini thermo-electric refrigerator with a capacity of 40 litres to maintain the temperature between $3^{\circ} \mathrm{C}$ to $23^{\circ} \mathrm{C}$ for the duration of half an hour. Prashant G. et al [1] developed a portable thermo electric refrigeration system for medical application which can achieve $40 \%$ to $60 \%$ of cooling effect as compare to conventional refrigerator. Murat Gökçek and Fatih Şahin [9] used a commercial refrigerator with $0.063 \mathrm{~m}^{3}$ capacity as water cooled thermoelectric refrigerator and reported that high coefficient of performance can be achieved with a suitable heat sink.

A mini bovine embryo freezer of one cubic feet capacity weighing $15 \mathrm{~kg}$ of ModelR206 is available for some biomedical applications which use liquid nitrogen [10]. Ahmet Çağlar [11] tested a thermo electric refrigerator varying the parameters such as fans speed, power of the Peltier device as well as temperature and optimized the operating conditions to achieve the maximum coefficient of performance. Wilson R.Nyemba et al [12] developed a portable prototype thermo electric refrigerator for the total cost of the product of $\$ 129$.

\section{Published By:}

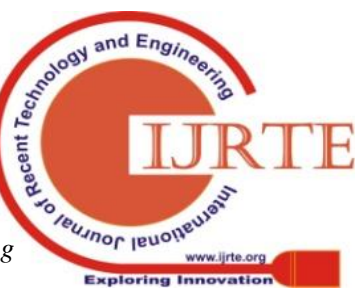




\section{Design and Manufacturing of Thermoelectric Mini Portable Refrigerator using Autodesk Fusion 360 and Additive Manufacturing}

It is reported that though the coefficient of performance is low, it is able to achieve the temperature of vaccines between $2^{\circ} \mathrm{C}-8^{\circ} \mathrm{C}$ with the minimum temperature of $6^{\circ} \mathrm{C}$ achieved in 5 hours from an ambient temperature of $23^{\circ} \mathrm{C}$. Selvam.C et al [13] conducted numerical studies and reported that the Peltier cooler with phase change material showed significant reduction in temperature under the electric square pulse condition.

Martinez.A et al [14] reported that increasing the voltage decreased the time required to lower the interior temperature and it is mentioned that for $24 \mathrm{~V}$, the time taken to reduce the temperature to $10^{\circ} \mathrm{C}$ is 49 minutes and it is also compared with the computational model. Suwit Jugsujinda et al [15] developed a thermoelectric refrigerator of size $25 \times$ $25 \times 35 \mathrm{~cm}^{3}$ and reported that one hour is the time taken to reduce the temperature from $30^{\circ} \mathrm{C}$ to $20^{\circ} \mathrm{C}$.

There is very little development of the prototype thermo electric refrigerators and the size and capacity of the thermoelectric refrigerator are generally large. Also the time taken to reduce the temperature is too long. Sometimes the medical fraternity may need a smaller version of thermoelectric refrigerator and less time to reduce the temperature of the cooling chamber. This paper explains about the development of a mini portable thermoelectric refrigerator whose body is manufactured using additive manufacturing and designed by Autodesk Fusion 360.

\section{SCOPE OF THE RESEARCH WORK}

The project aims to design and develop a lightweight, easy-to-operate, portable cylindrical refrigerator box using thermoelectric refrigeration which is capable of maintaining the temperatures of $8 \pm 2{ }^{\circ} \mathrm{C}$. The project intends to help safely store medicines while travelling or in case of any emergency situation like power-failure, environmental adversities like flood, earth-quake etc. The mini portable refrigerator is capable of setting different temperatures in the refrigerated space so the product can be used for more than one specific purposes.

\section{EXPERIMENTAL PROCEDURE AND METHODOLOGY}

In this research work, a cylindrical mini thermoelectric refrigerator is designed using Autodesk Fusion360. Two designs of the casing of the refrigerator are made using Autodesk Fusion 360 as shown in Fig.1a and Fig.1b. The design in Fig1b is selected for additive manufacturing. The dimensions of this casing are shown in Fig.2. The number of fins required for cooling and critical thickness of casing of the refrigerator is calculated based on the assumption of forced convection.

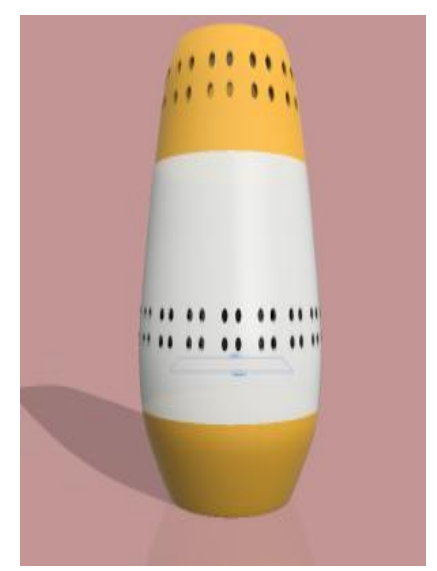

Fig.1a. Conical Casing

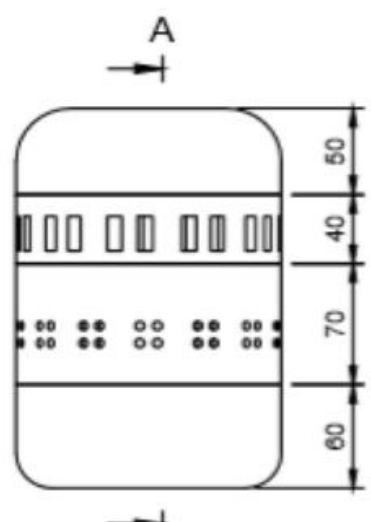

A

FRONT VIEW

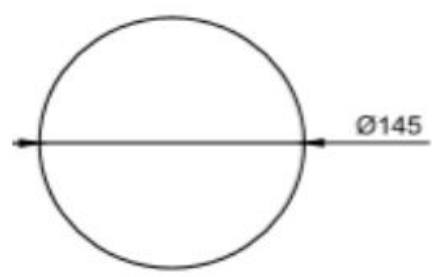

TOP VIEW

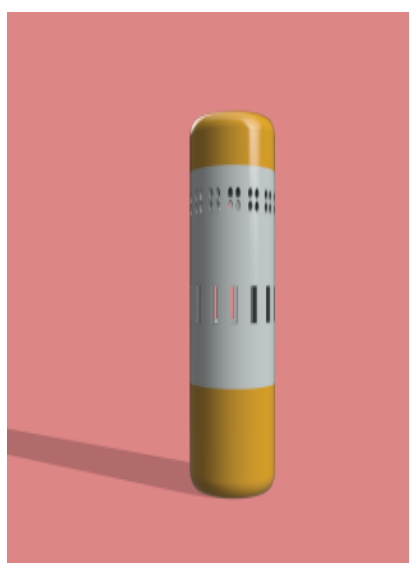

Fig.1b. Cylindrical casing

A-A (1:3)

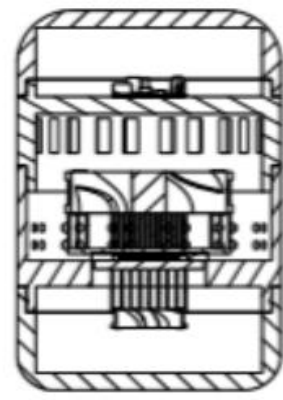

SECTION VIEW

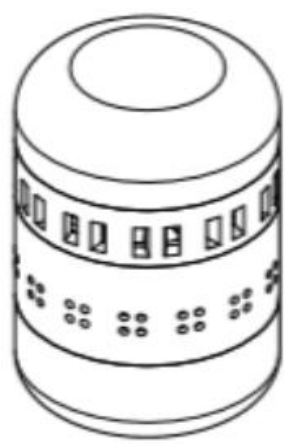

PICTORIAL VIEW

Fig.2. Dimensions and sectional view of the thermoelectric refrigerator

The various components required for this mini portable refrigerator such as thermoelectric (Peltier element TEC112706)) module, heat sink for cold side and hot side, fans, thermostat (W1209 digital temperature controller) for controlling the temperature of about 5 to $10^{\circ} \mathrm{C}$ in the refrigerator space, a $12 \mathrm{~V} / 5 \mathrm{~A}$ DC power adapter for power supply are selected as shown in Fig. 3 to Fig. 8 for assembling in the cylindrical casing.

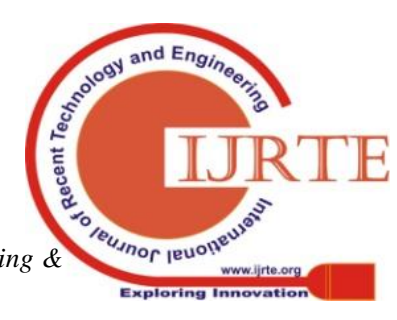


The casing material used is polylactide (PLA) which is biodegradable. The casing is fabricated by $3 \mathrm{D}$ printing (additive manufacturing) known as fused deposition modeling (FDM). Since this manufacturing process has many advantages such as freedom to design as per the customer requirement, green manufacturing, weight savings and useful for mass production, this process is selected to fabricate the casing.

All the components are assembled in the casing and the exploded view of the refrigerator is shown in Fig.9. The insulation material "Styrofoam" is a trademarked brand of closed-cell extruded polystyrene foam (XPS), commonly

called "Blue Board" is used to insulate the interior side of the wall of the casing. The circuit diagram is shown in Fig 10 for the connection of the various components of the thermo electric refrigerator.

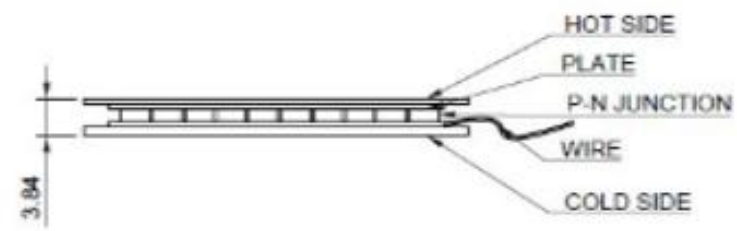

FRONT VIEW

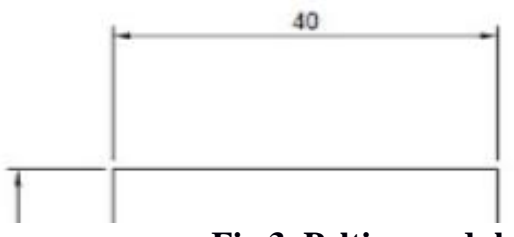

Fig.3. Peltier module

The assembly is tested for the effectiveness of cooling and maintenance of required temperature with and without the insulation. The same assembly is tested after housing it inside the cylindrical casing.

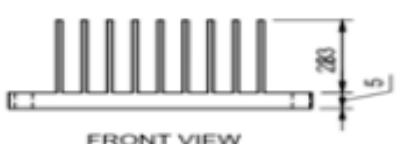

FRONT VEW

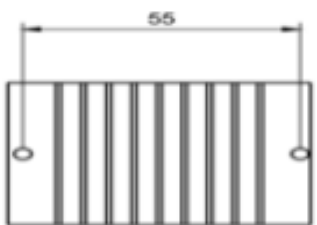

TOP VIEW

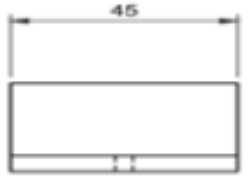

LEFT SIDE VIEW

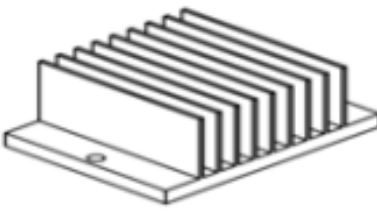

PICTORIAL VIEW

Fig.4. Cold side fin

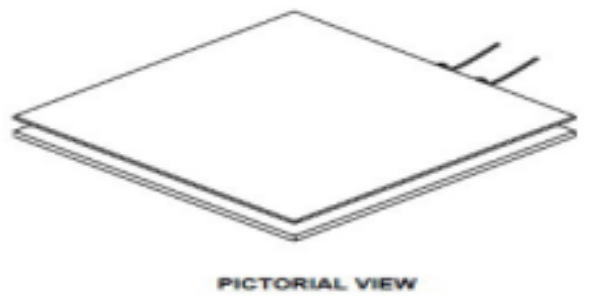

Fig.5. Hot side fin

Retrieval Number: E6560018520/2020@BEIESP

Published By:

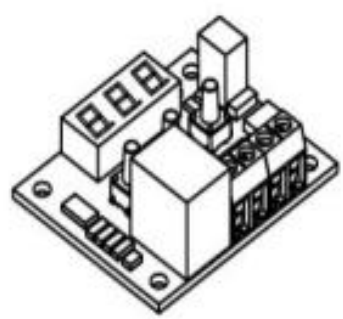

PICTORIAL VIEW

Fig.6. W1209 Thermostat

Fig.7 Exhaust fan

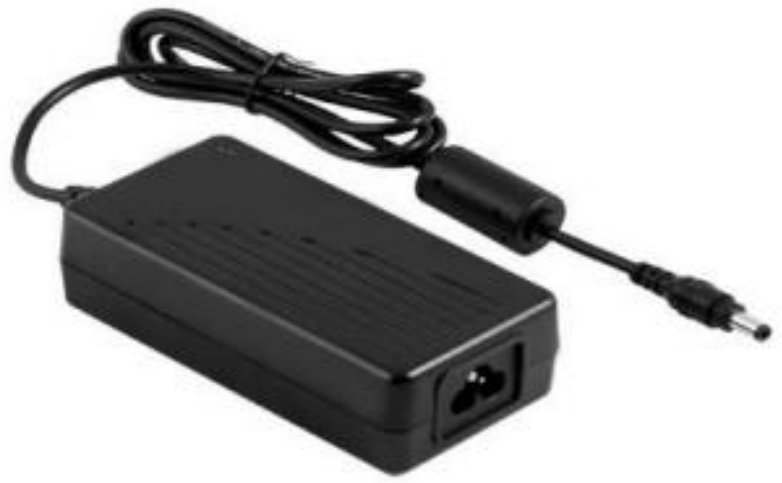

Fig.8. 12V, 5A DC power adapter supply

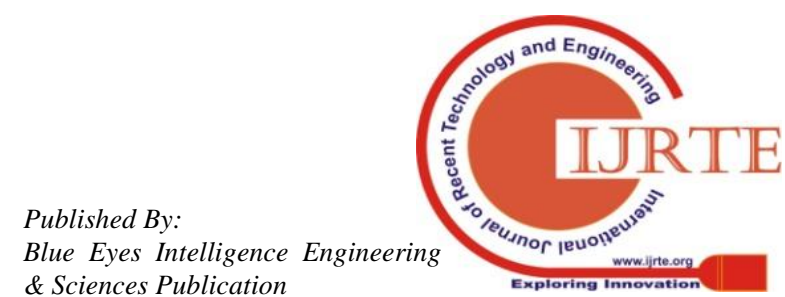



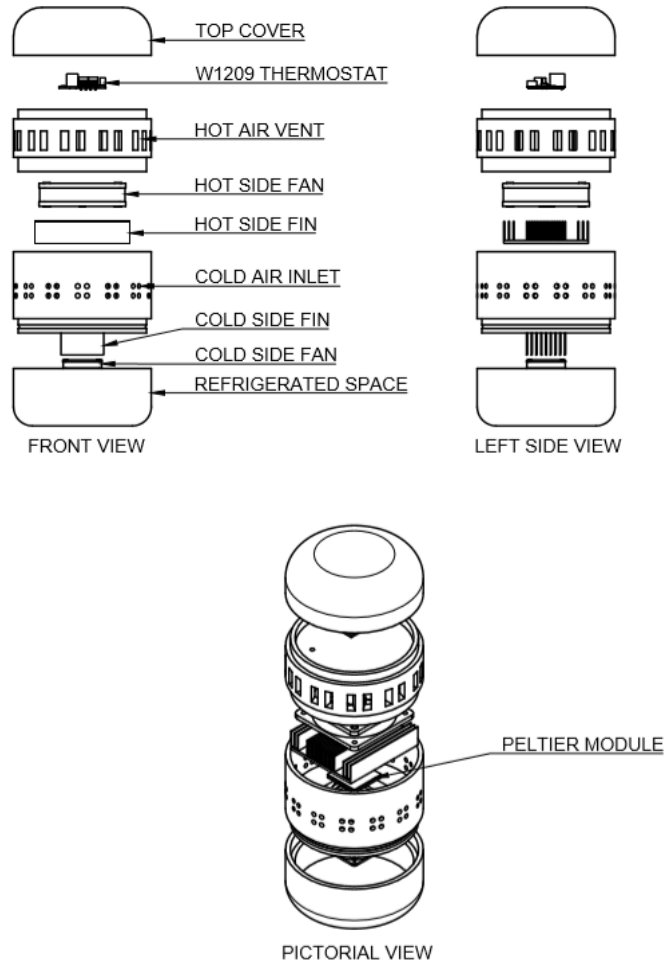

Fig.9. Exploded view of portable mini refrigerator

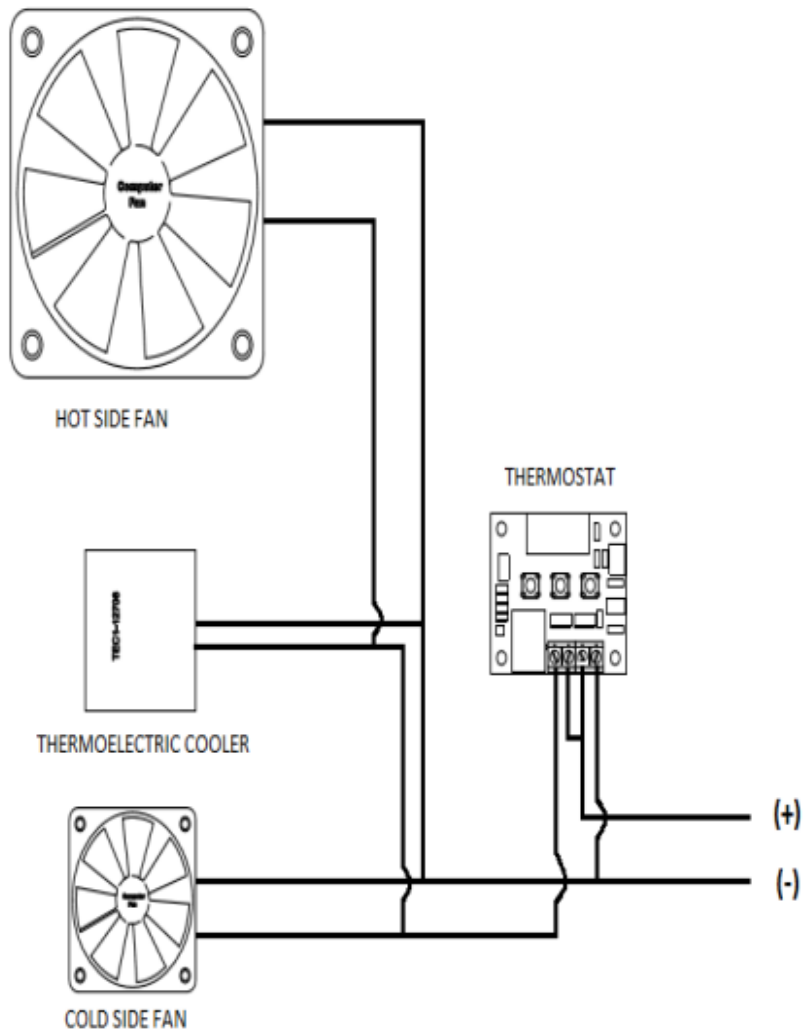

Fig.10. Circuit Diagram

\section{DESIGN CALCULATION FOR NUMBER OF FINS AND CRITICAL THICKNESS OF INSULATION}

\section{A. Fin calculation for forced convection}

The approximate number of fins required for efficient heat transfer in the refrigerator is calculated based on the formulae available in Ref. [16].
Fin Dimensions:

Length of one fin (l) $=2 \mathrm{~mm}$

Width of one fin (b) $=10 \mathrm{~mm}$

Thickness of one fin $(y)=1 \mathrm{~mm}$

Atmospheric temperature $\left(\mathrm{t}_{\mathrm{a}}\right)=32^{\circ} \mathrm{C}$

Base temperature $\left(\mathrm{t}_{\mathrm{o}}\right)=80^{\circ} \mathrm{C}$

Heat transfer coefficient (h) $=64 \mathrm{~W} / \mathrm{m}^{2}{ }^{\circ} \mathrm{C}$

Thermal conductivity of material $(\mathrm{K})=204.2 \mathrm{~W} / \mathrm{m}^{2}{ }^{\circ} \mathrm{C}$

Perimeter of one fin $(\mathrm{P}) \quad=2(\mathrm{~b}+\mathrm{y})$

$$
=2(0.1+0.001)
$$$$
=0.202 \mathrm{~m}
$$

Area of cross section $\left(\mathrm{A}_{\mathrm{cs}}\right)$

$=\mathrm{b} \times \mathrm{y}$

$$
=0.1 \times 0.001
$$$$
=1 \times 10^{-4} \mathrm{~m}^{2}
$$

Number of fins required= Heat dissipated from Peltier/Heat dissipated from one fin $\left(\mathbf{Q}_{\text {fin }}\right)$

$\mathbf{Q}_{\mathrm{fin}}=\sqrt{\text { PhKACs }}\left(\mathrm{t}_{\mathrm{o}}-\mathbf{t}_{\mathrm{a}}\right)\left[\frac{\tanh (\mathrm{ml})+\frac{\mathrm{h}}{\mathrm{Km}}}{1+\left[\frac{\mathrm{h}}{\mathrm{Km}} \times \tanh (\mathrm{ml})\right]}\right]$

Where,

$$
\mathrm{m}=\sqrt{\frac{\mathrm{hP}}{\mathrm{KAcs}}}
$$

$\mathrm{P}=$ Perimeter of fin $(\mathrm{m})$

$\mathrm{h}=$ Convective heat transfer coefficient $\left(\mathrm{W} /\left(\mathrm{m}^{2} \mathrm{~K}\right)\right.$

$\mathrm{K}=$ Thermal conductivity of the fin material $(\mathrm{W} /(\mathrm{mK})$

$\mathrm{l}=$ length of the fin $(\mathrm{m})$

$\mathrm{t}_{0}=$ Temperature at the base of the fin $(\mathrm{K})$

$\mathrm{t}_{\mathrm{a}}=$ Ambient temperature of air $(\mathrm{K})$

Substituting the data's in Eq (1),

$$
\begin{aligned}
\mathrm{m} & =\sqrt{\frac{\mathrm{hP}}{\text { KAcs }}} \\
& =\sqrt{\frac{20 \times 0.202}{204.2 \times 1 \times 10^{-4}}}=14.06
\end{aligned}
$$

$$
\begin{aligned}
& \mathbf{Q}_{\text {fin }}=\sqrt{\text { PhKAcs }}\left(\mathbf{t}_{\mathbf{o}}-\mathbf{t}_{\mathbf{a}}\right)\left[\frac{\tanh (\mathrm{ml})+\frac{\mathrm{h}}{\mathrm{Km}}}{1+\left[\frac{\mathrm{h}}{\mathrm{Km}} \times \tanh (\mathrm{ml})\right]}\right] \\
& =\sqrt{0.202 \times 64 \times 204.2 \times 1 \times 10^{-4}} \times
\end{aligned}
$$

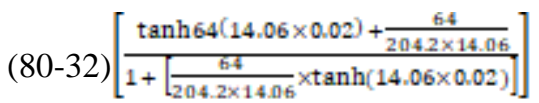

$$
=14.0581 \mathrm{~W}
$$

Heat dissipated from Peltier $=92 \mathrm{~W}$ as is given in the specification of the model TEC12706L in Table I [17]

$\therefore$ Number of fins required $=92 / 14.0581$

$$
=6.309=7 \text { fins }
$$

As per calculation 7 fins are required to dissipate about 92 $\mathrm{W}$ of heat.

\section{B. Design calculations of critical thickness of insulation}

A material which retards the flow of heat with reasonable effectiveness is known as insulation. Insulation serves the following two purposes.

(i) It prevents the heat flow from the system to surroundings.

Published By: 
(ii) It prevents the flow from surrounding to the system

In addition to the above purposes, the insulation always increases the conductive thermal resistance. The calculation of critical thickness of insulation in portable mini refrigerator is done as follow [16].

Length of the refrigeration space is, $L=6 \mathrm{~cm}$

Surface temperature of refrigeration space, $\mathrm{T}_{1}=7.5^{\circ} \mathrm{C}$

Temperature of air, $\mathrm{T}_{\text {air }}=28^{\circ} \mathrm{C}$

Heat transfer coefficient at outer surface,

$$
\mathrm{h}_{0}=20 \mathrm{~W} / \mathrm{m}^{2 \circ} \mathrm{C}
$$

Thermal conductivity of insulating material,

$$
\mathrm{k}=0.193 \mathrm{~W} / \mathrm{m}^{\circ} \mathrm{C}
$$

The rate of heat transfer (Q) from surface of solid cylinder to the surroundings

$\mathrm{Q}=\frac{\frac{2 \pi L\left(T_{1}-T_{\text {air }}\right)}{\ln \left(\frac{r_{2}}{r_{1}}\right)}}{K}+\frac{1}{h_{0} r_{2}}$

$\mathrm{r}_{1}=5.5 \mathrm{~cm}$, internal radius of the insulation

Where $\mathbf{r}_{2}=\mathbf{r}_{\mathrm{c}}=\frac{K}{h_{0}}$

$$
=\frac{0.193}{20}=0.965 \mathrm{~cm} \text { is the critical thickness or outer }
$$

radius of insulation.

$\mathrm{Q}=\frac{\frac{2 \pi 6 \times 10^{-2}(28-7.5)}{\ln \left(\frac{7}{5.5}\right)}}{0.193}+\frac{1}{20 \times 7 \times 10^{-2}}=3.93 \mathrm{~W}$

In this design the $r_{2}$ value is taken as approximately $1 \mathrm{~cm}$ $(0.965 \mathrm{~cm})$ and the $r_{1}$ value is taken as $7 \mathrm{~cm}$.

\section{V.COEFFICIENT OF PERFORMANCE}

The efficiency of a refrigerator or heat pump is given by a parameter called the coefficient of performance (COP).The general measure of efficiency of a TEC is based on the amount of heat that it removes compared to the amount of work that it requires. This value is referred to as coefficient of performance, COP. In this study we use TEC1-127-06L a thermoelectric module, whose specifications are given in the Table.I.

Table- I: TEC Specification

\begin{tabular}{|l|l|l|l|}
\hline \multicolumn{4}{|c|}{ Module: Model TEC12706L } \\
\hline $\mathrm{Q}_{\max }$ & $92 \mathrm{~W}$ & \multicolumn{2}{c|}{ Dimensions } \\
\hline $\mathrm{I}_{\max }$ & $6 \mathrm{~A}$ & Width & $40 \mathrm{~mm}$ \\
\hline $\mathrm{V}_{\max }$ & $15.4 \mathrm{~V}$ & Length & $40 \mathrm{~mm}$ \\
\hline $\mathrm{T}_{\max }$ & $138^{\circ} \mathrm{C}$ & Thickness & $3.6 \mathrm{~mm}$ \\
\hline $\begin{array}{l}\text { Number of } \\
\text { thermocouple }\end{array}$ & 127 & \multicolumn{3}{|l}{} \\
\hline
\end{tabular}

The thermoelectric cooler module material chosen is Bismuth telluride. The properties of a 127 couple, 6A Bismuth Telluride module TEC1-127-06L are taken from ref [17] as follow:

Seebeck coefficient $(\mathrm{S})=0.01229 \mathrm{~V} / \mathrm{k}$, Module thermal conductance $(\mathrm{K})=0.1815 \mathrm{~W} / \mathrm{k}$, Module resistance $(\mathrm{R})=$ $4 \Omega$.

$\mathrm{Q}_{\mathrm{L}}=-\left[\operatorname{SIT}_{\mathrm{C}}-\left(\mathrm{I}^{2} \mathrm{R} / 2\right)-\mathrm{k}\left(\mathrm{T}_{\mathrm{h}}-\mathrm{T}_{\mathrm{c}}\right)\right]$

The negative sign indicates the heat rejection.

The heat transferred out of the hot side into the heat sink is given by

$$
\mathrm{Q}_{\mathrm{H}}=\mathrm{SIT}_{\mathrm{h}}+\left(\mathrm{I}^{2} \mathrm{R} / 2\right)-\mathrm{k}\left(\mathrm{T}_{\mathrm{h}}-\mathrm{T}_{\mathrm{c}}\right)
$$

COP can be calculated by dividing the amount of heat absorbed at the cold side to the input power.

$$
\mathrm{COP}=\frac{Q_{L}}{\text { Energy supplied }}
$$

Heat absorption is calculated as below.

$$
\begin{aligned}
\mathrm{Q}_{\mathrm{L}} & =-\left[\mathrm{SIT}_{\mathrm{c}}-\left(\mathrm{I}^{2} \mathrm{R} / 2\right)-\mathrm{k}\left(\mathrm{T}_{\mathrm{h}}-\mathrm{T}_{\mathrm{c}}\right)\right] \\
& \left.=-[(0.01229 \times 6 \times 10))-\left(6^{2} \times 4 \times .5\right)-(0.1815 \times 70)\right] \\
& =83.92 \mathrm{~J}
\end{aligned}
$$

The energy supplied based on the first law of thermodynamics is:

Energy supplied, $\mathrm{W}=\mathrm{Q}_{\mathrm{H}}-\mathrm{Q}_{\mathrm{L}}$

$$
\begin{aligned}
& =\mathrm{SI}\left(\mathrm{T}_{\mathrm{h}}-\mathrm{T}_{\mathrm{c}}\right)+\mathrm{I}^{2} \mathrm{R} \\
& =(0.01229 \times 6 \times 70)+\left(6^{2} \times 4\right) \\
& =149.16 \mathrm{~J}
\end{aligned}
$$

Where, COP-Coefficient of Performance

I-Current

k-Thermal conductivity

$\mathrm{Q}_{\mathrm{H}}$-Heat rejection

$\mathrm{Q}_{\mathrm{L}}$-Heat absorption

R-Electric Resistance

TEC-Thermoelectric cooler

P-Power consumption

W-Energy supplied

Temperature at hot side $\mathrm{T}_{\mathrm{h}}=80^{\circ} \mathrm{C}$, Temperature at cold side $\mathrm{T}_{\mathrm{c}}=10^{\circ} \mathrm{C}$

The Coefficient of Performance (COP) is calculated using equation (7) and its value is found to be 0.5626 .

\section{RESULTS AND DISCUSSION}

The prototype of mini portable refrigerator casing manufactured by fused deposition modelling is shown in Fig 11. All the components of the refrigerator are assembled as shown in the exploded view in Fig.9 inside this casing. The component assembly (Fig. 12) without the casing was tested in a styrofoam insulated volume of $432 \mathrm{~cm}^{3}$ to verify the temperature versus time to reach the required temperature.

The test results given in Fig 13 shows that in 20 minutes time the temperature attained is $18.4^{\circ} \mathrm{C}$ without insulation whereas it is $10^{\circ} \mathrm{C}$ with insulation. The same assembly after fixing in the casing is also tested and found to give approximately same temperature of $10^{\circ} \mathrm{C}$ within twenty minutes time. It is reported that the COP for portable prototype thermo electric refrigerator is varied from $0.083[12]$ to 0.65 [15].
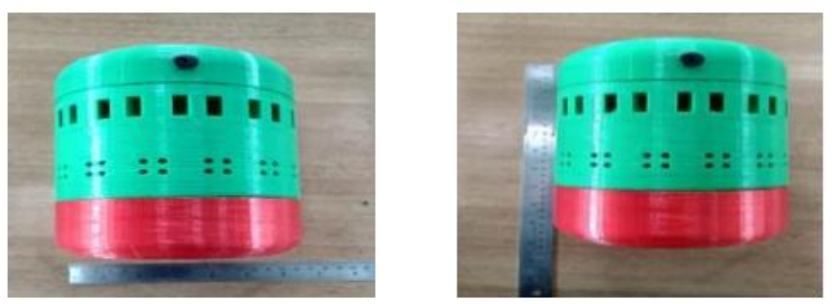

Fig.11. Cylindrical mini portable refrigerator casing. 


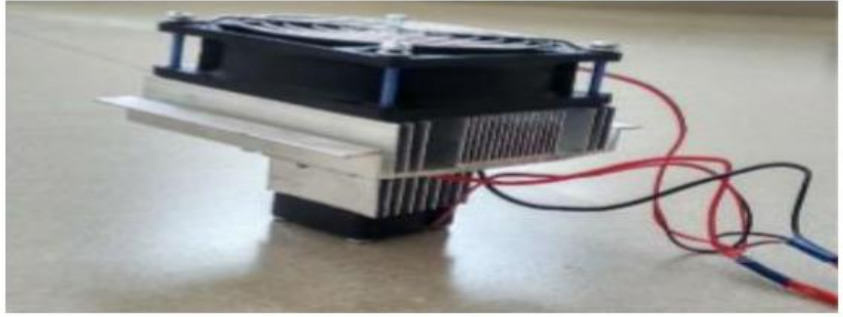

Fig.12. Component assembly

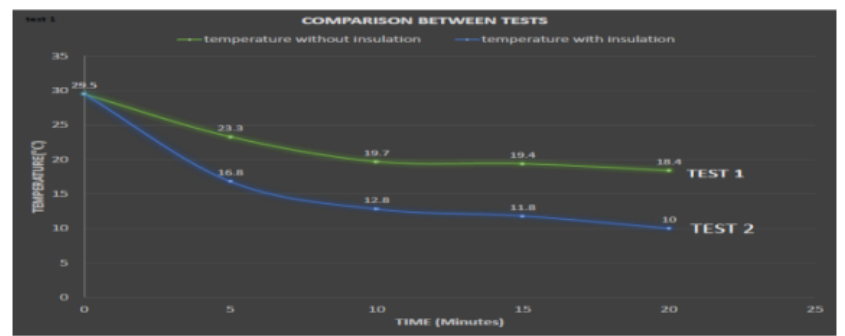

Fig.13. Temperature versus time during the refrigeration process

The total volume of space available in this refrigerator casing is about $645 \mathrm{~cm}^{3}$. With this space and refrigeration capacity it may be used for storing and transporting many medicines. The power supply is rechargeable using any power bank.

\section{CONCLUSIONS}

The mini portable refrigerator is designed using Autodesk Fusion 360 and manufactured by 3D printing using polylactide material. The approximate manufacturing cost of this refrigerator is $\$ 75$.

This portable refrigerator is compact, less weight, aesthetic and able to maintain the inside temperature of 8 to $10^{\circ} \mathrm{C}$. The COP is 0.56 and it can be used for storing medicines and other small items which needs to be maintained at this temperature.

\section{ACKNOWLEDGMENT}

We highly acknowledge the technical guidance given by Dr.Aneesh Prabhakar, Assistant professor, Center for Energy and Environment, Malaviya National Institute of Technology, Jaipur, India and Mr.Rojo Kurian Daniels, Assistant professor, Department of Mechanical Engineering, Providence College of Engineering, Chengannur, Kerala.

\section{REFERENCES}

1. Prashant G., Sonkhede and A. K. Pathrikar, Portable Thermoelectric Refrigeration System for Medical Application, International Journal of Innovative Research in Computer and Communication Engineering, Vol. 4, Issue 3, March 2016, pp3190-3195.

2. N A Mezaal, K V Osintsev, T B Zhirgalova, Review of magnetic refrigeration system as alternative to conventional refrigeration system, IOP Conf. Series: Earth and Environmental Science 87 (2017) 032024.

3. T. Somasekhar, P.Naveen Kishore (2017), Thermo Acoustic Refrigeration, IOSR Journal of Mechanical and Civil Engineering (IOSR-JMCE) e-ISSN: 2278-1684,p-ISSN: 2320-334X PP. 58-63

4. Narendra .N .Wadaskar, Dr S.K.Choudhary, Dr R.D.Askhedkar, Analysis of Coefficient of Performance \& Heat Transfer Coefficient on Sterling Cycle Refrigeration system, Int. Journal of Engineering Research and Application , Vol. 7, Issue 8, (Part -5) August 2017, pp.78-85.
5. Wenjie Nie, Jizhou Heb, Jianqiang Dua, Performance characteristic of a Stirling refrigeration cycle in micro/nano scale, Physica A 388 (2009) 318324.

6. Dongliang Zhao and Gang Tan, A review of thermoelectric cooling: Materials, Modeling and applications, Applied Thermal Engineering 66 (2014) 15-24.

7. Simone Mancin, Claudio Zilio, Giulia Righetti and Luisa Rossetto, Mini Vapor Cycle System for high density electronic cooling applications, International Journal of Refrigeration, 36, 2013, pp1191-1202

8. Elavarasan E, Saravanan S, Abhishek Kumar, Anaitullah, Ashok Sah and Karan Kumar S,Design and Fabrication of Mini Refrigerator with Thermoelectric Cooling, International Journal of Engineering Research \& Technology (IJERT), Special Issue 2018, Vol.6, Issue 10, pp1- 4.

9. Murat Gökçek and Fatih Şahin, Experimental performance investigation of minichannel water cooled-thermoelectric refrigerator, Case Studies in Thermal Engineering 10 (2017) pp54-62.

10. Industrial News, International Journal of Refrigeration, Vol.10, January 1987, pp59-60.

11. Ahmet Caglar, Optimization of operational conditions for a thermoelectric refrigerator and its performance analysis at optimum conditions, International Journal of Refrigeration, 2018, pp2-19.

12. Wilson R. Nyembaa.b, Simon Chinguwab, Batsirayi L. Marangoa and Charles Mbohwa, Evaluation and feasibility assessment of the sustainability of refrigeration systems devoid of harmful refrigerants for storage of vaccines, 2nd International Conference on Sustainable Materials Processing and Manufacturing (SMPM 2019), Procedia Manufacturing 35 (2019) 291-297.

13. Selvam.C, S. Manikandan, S.C. Kaushik, Ravita Lamba, Sivasankaran Harish, Transient performance of a Peltier super cooler under varied electric pulse conditions with phase change material, Energy Conversion and Management 198 (2019) 111822.

14. A.Martinez, D. Astrain, A. Rodriguez, P. Aranguren, Advanced computational model for Peltier effect based refrigerators, Applied Thermal Engineering 95 (2016) 339-347.

15. Suwit Jugsujinda*, Athorn Vora-ud, and Tosawat Seetawan, Analyzing of Thermoelectric Refrigerator Performance, $2^{\text {nd }}$ International Science, Social-Science, Engineering and Energy Conference 2010: Engineering Science and Management, Procedia Engineering 8 (2011) 154-159

16. Kothandaraman.C.P and Subramanyan.S (2018) Heat and mass transfer data book, New Age International 9th 2018.

17. Jatin Patel, Matik Patel, Jigar Patel, Himanshu Modi, Improvement In The COP Of Thermoelectric Cooler, International Journal Of Scientific \& Technology Research Volume 5, Issue 05, May 2016, pp73-76.

\section{AUTHORS PROFILE}

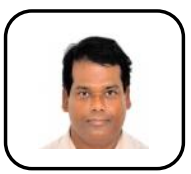

Dr. K. Angamuthu is a mechanical engineering graduate, received his Ph.D degree from IIT, Madras in the year 2000. He has about 33 years of experience in teaching and research, worked in different capacities as Professor, Director and Dean in different universities and engineering institutes in India and abroad. His areas of interest are materials engineering and cryogenic engineering. He has twenty papers to his credit in the conferences and journals. Currently he is working as professor and head of department of mechanical engineering, Providence College of Engineering, Chengannur, Kerala, India.

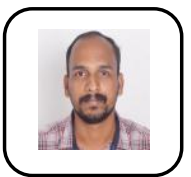

Mr.Ashu Dominic is a trainee engineer in the department of mechanical engineering, Providence College of Engineering, Chengannur, Kerala.

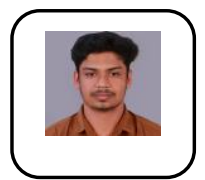

Mr. Arun Kumar. $\mathbf{H}$ is $\mathbf{s}$ trainee engineer in the department of mechanical engineering, Providence College of Engineering, Chengannur, Kerala. 
Mr. Sahil $\mathbf{S}$ is a trainee engineer in mechanical engineering department, Providence College of Engineering, Chengannur, Kerala.

Mr. Jofin Sam is a trainee engineer in mechanical engineering department, Providence College of Engineering, Chengannur, Kerala. 